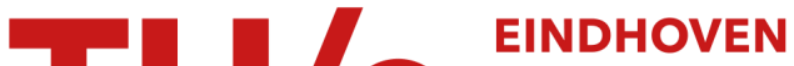 UNIVERSITY OF TECHNOLOGY
}

\section{Lot-sizing and flow production in an MRP-environment}

\author{
Citation for published version (APA): \\ Frijters, C. H. M., Kok, de, A. G., \& Wessels, J. (1988). Lot-sizing and flow production in an MRP-environment. \\ (Memorandum COSOR; Vol. 8814). Technische Universiteit Eindhoven.
}

Document status and date:

Published: 01/01/1988

\section{Document Version:}

Publisher's PDF, also known as Version of Record (includes final page, issue and volume numbers)

\section{Please check the document version of this publication:}

- A submitted manuscript is the version of the article upon submission and before peer-review. There can be important differences between the submitted version and the official published version of record. People interested in the research are advised to contact the author for the final version of the publication, or visit the $\mathrm{DOI}$ to the publisher's website.

- The final author version and the galley proof are versions of the publication after peer review.

- The final published version features the final layout of the paper including the volume, issue and page numbers.

Link to publication

\section{General rights}

Copyright and moral rights for the publications made accessible in the public portal are retained by the authors and/or other copyright owners and it is a condition of accessing publications that users recognise and abide by the legal requirements associated with these rights.

- Users may download and print one copy of any publication from the public portal for the purpose of private study or research.

- You may not further distribute the material or use it for any profit-making activity or commercial gain

- You may freely distribute the URL identifying the publication in the public portal.

If the publication is distributed under the terms of Article 25fa of the Dutch Copyright Act, indicated by the "Taverne" license above, please follow below link for the End User Agreement:

www.tue.nl/taverne

Take down policy

If you believe that this document breaches copyright please contact us at:

openaccess@tue.nl

providing details and we will investigate your claim. 
Memorandum CoSOR 88-14

Lot-sizing and flow production

in an MRP-environment

by

L. Frijters, T. de Kok, J. Wessels 


\title{
Lot-sizing and flow production in an MRP-environment
}

\author{
by \\ Lilian Frijters ${ }^{1}$ \\ Ton de Kok ${ }^{1}$ \\ Jaap Wessels ${ }^{2}$
}

\begin{abstract}
In the paper methods are developed to analyze a production process for professional equipment with advanced electronic and mechanical features. The starting point of the analysis is to find ways for production control and production organization which maintain and even strenghten the advantages of the MRP-system, but also mend the disadvantages to a large extent. The main advantages which could be further improved are the lead times for customer orders and the inventories of buy-parts and subassemblies. The disadvantages which should be mended are high costs of order releases, materials handling and data processing.
\end{abstract}

Philips, Eindhoven, the Netherlands

2 Technical University, Eindhoven, the Netherlands 


\section{Introduction}

A quite usual situation for the production of professional equipment is that orders are produced on customer specification within families of products. It is also quite usual that products contain many parts of which several are standard and multi-purpose but several others are specifically made for this line of products. Production control for this type of production is complex. Many producers of professional equipment have difficulties with efficiency (irregular use of capacities; high inventories) and with the effectiveness required by the market (lead times with respect to length and predictability; quality). MRP-based control and information systems can be of great help in improving the main performance characteristics. Nevertheless, such systems still have some disadvantages and even the strong points might get some improvement. In this paper we consider a situation which is based on a practical case. We present our analysis of this particular situation since we believe that the concepts which have been developed have a much wider application after appropriate modification. Emphasis in our analysis is on lot-sizes and consequently on lead times and stock of subassemblies. After the description of the situation in section 2, we will investigate the sensitivity of costs and lead times to changes in lot-sizes. Since it will appear that with the current organization short lead times and small lot-sizes will lead to high costs, several alternative ways of controlling production are considered (section 3). A side constraint is always that altematives should be realizable withing COPICS. These alternatives lead to substantial cost reductions but lot-sizes remain large and lead times remain long. Section 4 is devoted to an alternative which also has a great effect on the work floor: flow production. It is investigated how flow production (in essence: lot-sizes equal to one) might be organized withing COPICS and what would be the consequences. Within this altemative the possibility is considered to produce some subassemblies in larger series. A simple heuristic procedure is developed to determine which subassemblies can best be kept outside the flow.

Acknowledgement: the authors gratefully acknowledge the contribution to the forming of their ideas of the discussions with Mr. H. Mulder and Mr. W. de Jager of Philips' Medical Systems Division.

\section{Product and production}

We consider an advanced technological piece of equipment which is used in hospitals, an $X$-ray apparatus say. The final production stages consist of assembling and testing. The inputs of this phase are bought from specialized outside firms or from specialized factories withing the company. A set of workshops takes care for the final assembly and testing of a family of strongly related products each consisting of several hundreds parts. The production structure is determined by the product structure, which is a built-up of sub-assemblies. A workshop is responsible for one or more (sub-) assemblies. For an example, see figure 1. 


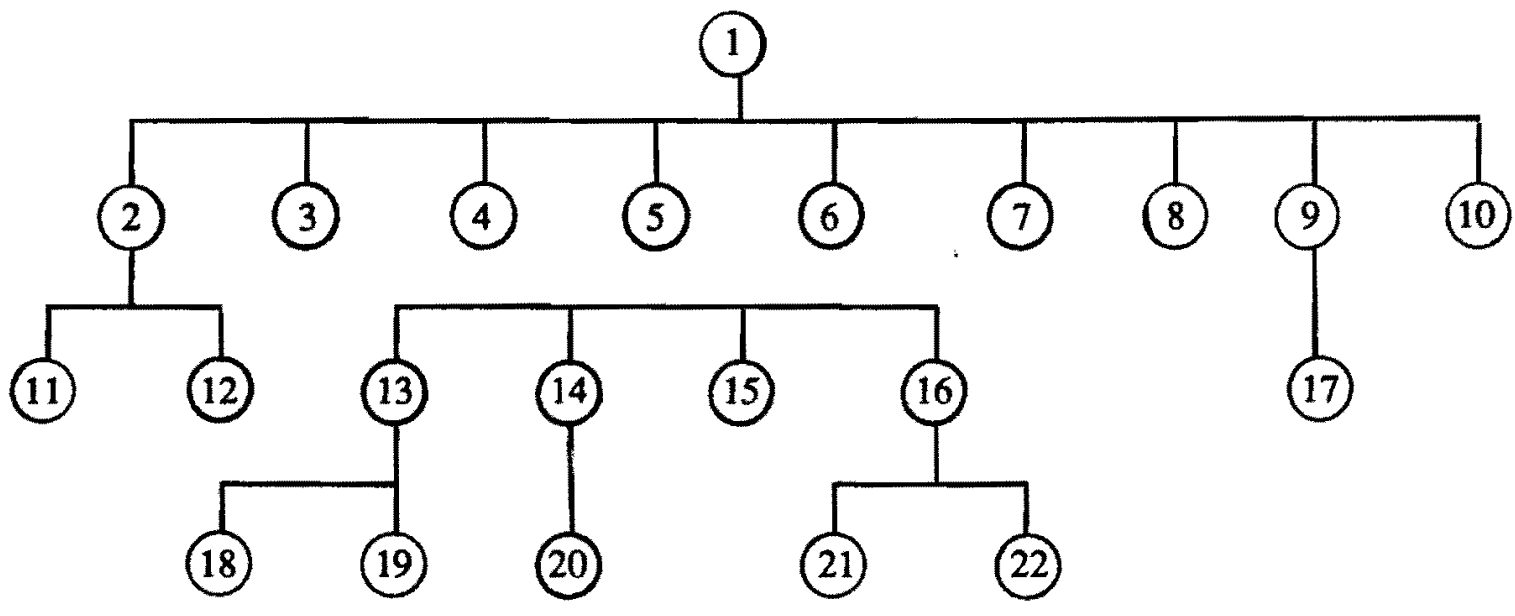

fig. 1: The product structure: each circle represents a (sub-) assembly containing the indicated subassemblies with higher number; the final product bears number one, the other numbers represent intermediate subassemblies.

A (sub-) assembly may contain other subassemblies but it certainly needs components from stock. All (extemally bought) components are being kept in stock.

The existing production control consists of a relatively straightforward implementation of MRP II with the following features:

- Master production schedule (MPS) is made on the level of final products.

- The component inventories act as decoupling point: components are ordered on the basis of forecasts, whereas (sub-) assemblies are only produced on the basis of sales contracts and (slightly) customer specifications.

- The four core modules of COPICS are used for the actual registration and scheduling:

Bill of Materials

Inventory accounting

MRP-I (explosion, buy orders, manufacturing orders)

Shop order release.

The other features of the complex planning organization are not of importance here and are therefore deleted. The only important fact to know is that as a result of the coordination of sales and production the demand is rather smooth with respect to the number of ordered systems per week.

This production control system has been installed recently and appears to have advantages and disadvantages. We name the most important ones:

\section{Advantages:}

smooth production with considerable increase of throughput;

a considerable decrease of inventories;

better (i.e. shorter and more predictable) lead times for customer orders 
and stocks.

\author{
Disadvantages: \\ many releases for manufacturing orders; \\ excessive costs for material handling; \\ expensive data handling and computing.
}

The first purpose for the present investigation is to see whether advantages can be further improved (particularly with respect to the lead times and the sizes of the inventories), while also improvement with respect to the disadvantages would be welcome.

In fact, during the introduction of the new control system one has decreased lot-sizes and one would like to proceed in that direction with lot sizes equal to one as ultimate goal. Combined with a "just-in-time" approach this would lead to very short lead times and low inventories.

A disadvantage of MRP which has not been mentioned as such is that MRP is not oriented towards efficient exploitation of capacities. This disadvantage is not important in practice as long as the coordination between sales force and production is such that the effective demand for the production department is relatively constant. For our setting of manufacturing medical equipment this means that we assume that demand in numbers of systems is constant and that this demand level only changes on longer notice. Within this assumption the type mix of sold systems might show more nervousness.

\title{
3. Optimal lot-sizes and alternative organisations
}

As stated in the previous section, the ultimate goal is "lot-sizes equal to one". However, the experience so far has shown that decreasing of lot-sizes gives an increase in the number of order releases and in the number of material-handling operations. This effect might become prohibitive for essential decreases in lot-sizes.

Therefore, the first aim of this section is to see what could be sensible lot-sizes within the current organisation. If very small lot-sizes would not be sensible, then the second aim would become to see whether alternative ways of organising production control (within the given MRP-setting) would make small lot-sizes appropriate.

We first model the problem of determining lot-sizes for the (sub-) assemblies. As usual we only consider lot-sizes which are multiples of the lot-size of the sub-assembly which is the predecessor in the product structure (note that the final product has number one). So sub-assembly 11 is produced in a lot which is a multiple of the lot-size of subassembly 2 (see Williams [3]). As stated in section 2 we assume a constant demand (in the example: four final products per week).

We consider four types of costs:

$\alpha \quad$ : costs for any release of an order for a (sub-) assembly;

$\beta \times n_{i}$ : costs for material handling of any order of (sub-) assembly $i$, where $n_{i}$ is the number of components from (central) inventory which are needed to produce one piece; 
$\gamma \times m_{i}:$ inventory cost per year for the material added in subassembly $i$ (material value $m_{i}$ );

$\delta \times l_{i}$ : inventory cost per year for the labour added in subassembly $i$ (labour value $l_{i}$ ).

In fact also obsoleteness risk has been taken into account, but because of its apparent insignificance in the examples at hand it will be left out in the presentation.

In this cost model the costs of ordering components and stock them are not taken into account. This has been done partly since changes in order-sizes for subassemblies will not essentially influence costs for components. Of course, however, the ultimate goal in the company is to use smaller order quantities for components too. A second reason to leave the component inventories out is that modelling is much more complicated because of the differences in the ordering and delivery process. The costs as stated can be estimated easily with at least some degree of accuracy. So, $\alpha$ just represents the costs of all the paper shuffing to be executed for an orderrelease and is estimated in the example at Dfl $180 .=$. Similarly, $\beta$ represents the costs of procuring one component in the right amount from the central stocks and is estimated in the example at Df 7.50. The parameters $\gamma$ and $\delta$ represent interest losses on invested money and are estimated at 0.2 on a yearly basis in the example.

Finally, a production time of $v_{i}$ for one piece of (sub-) assembly $i$ is specified. This production speed is necessary to determine when production of a lot should start. Material inventory costs are due from the start of production for a lot of a (sub-) assembly, whereas labour costs are supposed to be spread equally over the production time of a lot. There are also some technical (upper) bounds on lot-sizes.

For the computation of optimal lot-sizes a dynamic programming approach has been used, more specifically a relatively efficient method developed in Van Beek et al. [1], since a computer program for this method was available. for a more general overview of this problem ficld see Heinrich, Schneeweiss [2].

Table 1 compares for the example of fig. 1 optimal lot-sizes with the ones current at the moment of investigation.

\begin{tabular}{|l|rrrrrrrrrrr|}
\hline sub-assembly & 1 & 2 & 3 & 4 & 5 & 6 & 7 & 8 & 9 & 10 & 11 \\
\hline current lot-size & 15 & 15 & 60 & 15 & 15 & 60 & 60 & 60 & 15 & 15 & 150 \\
optimal lot-size & 9 & 72 & 72 & 36 & 18 & 135 & 198 & 54 & 18 & 18 & 288 \\
\hline
\end{tabular}

Table 1: lot-sizes for 11 (sub-) assemblies of the example.

It will be clear that most current lot-sizes are already below the optimal sizes.

Table 2 compares the costs of the current and the optimal situation. Also the "average" lead times are given. It is clear that the lead times are much better than in the optimal situation. The set-up costs combine the order release and material handling costs. 


\begin{tabular}{|l|r|r|l|}
\hline & current & optimal & \\
\cline { 1 - 3 } set-up costs & 1119 & 817 & costs in Df \\
inventory costs & 660 & 704 & per day \\
total costs & 1779 & 1521 & \\
\hline \hline "average" lead times & 37 & 66 & in days \\
\hline
\end{tabular}

Table 2: costs and lead times for the example.

It will be clear that a further slight diminishing of lot-sizes will be possible without incurring excessive extra costs. However, really small lot-sizes incur extra costs which can by no means be compensated by the diminishing of inventory costs (an explicit example will be given in the next section).

Apparently, just diminishing lot-sizes is the wrong way and therefore some obvious altematives will be investigated. Remind that the aim still is a just-in-time production with the appropriate lead time of 6 days without too much set-up costs.

Table 3 gives the optimal costs and the appropriate lead times for some alternatives. The alternatives are described below:

A: The set-up costs are halved in order to see the sensitivity of the lot-sizes and lead times for changes in the set-up costs.

B: The production control is changed in such a way that the procurement of components and the actual production are decoupled; this might make it possible to produce in small lots. For the model it means that each assembly stage is split in two. The material handling costs now only are incurred in the component procurement step. As an optimistic assumption the original order release costs are equally divided over the two steps.

C: The production control is changed in such a way that some subassemblies are merged into one. In COPICS this can be executed by making some stages phantom. A simple criterion is used to decide on these merges. As a result 8 subassemblies become phantom and 14 subassemblies remain active.

D: A combination of B and C: first merge and then split.

\begin{tabular}{|l|r|r|r|r|}
\hline & \multicolumn{1}{|c|}{ A } & \multicolumn{1}{c|}{ B } & \multicolumn{1}{c|}{ C } & \multicolumn{1}{c|}{ D } \\
\hline set-up costs & 608 & 649 & 797 & 628 \\
inventory costs & 403 & 554 & 690 & 537 \\
\hline total costs & 1011 & 1203 & 1487 & 1165 \\
\hline \hline "average" lead times & 44 & 53 & 44 & 38 \\
\hline
\end{tabular}

Table 3: Optimal costs and appropriate lead times for some alternatives in the example.

Without giving detailed tables of optimal lot-sizes for the alternatives, it will be clear from the lead times that lot-sizes remain essentially large. Therefore, some more rigorous steps seem to be necessary. Section 4 will be devoted to these steps. 


\section{Flow production}

In this section some more rigorous steps are taken into account in order to shorten lead times drastically without increasing costs essentially. In this section we use a similar but more complex example (it counts 47 subassemblies). The example represents a situation of a renewed family of products for which a new production environment is being developed. This environment implies a flow production on the workfloor. However, the production should remain MRP-controlled, although the flow production is installed for a fixed production rate of 4 systems a week. The systems may vary slightly.

The first alternative to the standard way of control is to provide cheap and small components in bulk on the workfloor. This is possible in COPICS by specifying a review period. Practically this means that these components are replenished 6 times a year. In the example this approach has been chosen for about 600 out of 800 components. Again it appears that the alternative has a positive influence on performance but not drastic (table 4 , columns $A$ and $B$ for the optimal costs without and with provision in bulk on the workfloor of cheap and small components).

The natural production control for flow production with the existing production structure would be to release an order for each subassembly each day, i.e. all lot-sizes would be equal to 4 . Columns $C$ and D of table 4 show costs and lead times for these lot-sizes for the standard situation and for the situation with cheap components in bulk on the workfloor. Compared with the optimal lot-sizes of columns A and B the cost-increases are dramatic.

A drastic measure would be to make all subassemblies phantom and only release a daily order for the end product. As a result all 200 remaining components are brought to the workfloor as soon as the first production stage of an order starts. The results are shown in table 4, column E. Finally, we have a set-up which is favorable with respect to costs and with respect to lead times.

\begin{tabular}{|l|rrrrr|}
\hline & A & B & C & D & E \\
\hline set-up costs & 2216 & 1840 & 14415 & 9660 & 1380 \\
inventory costs & 2173 & 1602 & 845 & 845 & 1227 \\
\hline total costs & 4389 & 3442 & 15260 & 10505 & 2607 \\
\hline \hline "average" lead time & 55 & 50 & 6 & 6 & 6 \\
\hline
\end{tabular}

Table 4: costs per day and lead times in days for several altematives for production control.

Of course it is not always sensible to work so strictly in flow as was proposed for the example. Therefore we developed a simple heuristic to check whether it would be sensible to produce some of the subassemblies in series. In fact we see in table 4 that column $E$ (flow production with all subassemblies phantom) that inventory costs increased compared to $C$ and $D$. This might be influenced by bringing expensive components which are only needed in the final steps already at production start to the workfloor. On the other hand some subassemblies might have technical set-up times and therefore extra large set-up costs and also therefore larger series might be sensible. The heuristic works either top-down or bottom-up. This means that all subassemblies are screened subsequently in order to decide to take them out of the flow. In the present example this 
cannot help essentially. Indeed, only 5 to 10 percents can be gained in costs (which are only a small part of the real costs) with a considerable prize in lead times. The program also gives the possibility to evaluate suggestions of the user. For more details see a forthcoming paper of the authors.

\section{Conclusions}

It is indeed possible to investigate with simple mathematical models how costs, lot-sizes and lead times behave for different alternative ways of production control within a rather rigid MRPsystem. This possibility can be exploited efficiently to construct feasible alternatives.

\section{References}

[1] P. van Beek, A. Bremer, C. van Putten: Design and optimization of multi-echelon assembly networks: savings and potentialities. Europ. J. Oper. Res. 19 (1985) 57-67.

[2] C. Heinrich, Ch. Schneeweiss: Multi-stage lot-sizing for gneral production systems. In: S. Axsäter et al, (eds.): Multi-stage production planning and inventory control. Springer, Berlin 1986.

[3] J.F. Williams: On the optimality of integer lot-size ratios in "economic lot-size determination in multi-stage assembly systems". Manag. Sci. 28 (1982) 1341-1349. 